\title{
Exceptional Rainfall Characteristics Related to Erosion Risk in Semiarid Tunisia
}

\author{
S. Jebari ${ }^{*}$, R. Berndtsson ${ }^{2}$, A. Bahri ${ }^{3}$ and M. Boufaroua ${ }^{4}$ \\ ${ }^{I}$ National Research Institute for Rural Engineering, Waters, and Forestry, Box 10, Ariana 2080, Tunis, Tunisia; \\ ${ }^{2}$ Department of Water Resources Engineering, Lund University, Box 118, S-22100 Lund, Sweden; ${ }^{3}$ International Water \\ Management Institute, PMB, CT 112, Cantonments Accra, Ghana; ${ }^{4}$ Farmland Conservation and Management Depart- \\ ment, 30, Alain Savary Street, 1002 Tunis, Tunisia
}

\begin{abstract}
The Tunisian Dorsal area is representative of the semiarid Mediterranean region in terms of water resources availability as well as exceptional rainfall characteristics, runoff generation, and soil loss risk. In this context, soil properties, surface management practices together with highly intensive rainfall make the soils vulnerable to erosion. If the exceptional rainfall characteristics are linked to different erosion types, the erosion risk could be evaluated in a simple and straightforward way. In this regard, a short time-scale rainfall data base from the Dorsal area was analysed in the paper. The procedure used involves finding a representative duration between 1-60 min for the exceptional rainfall characteristics. Rainfall intensities of different return periods are then related to the different erosion types. The identified exceptional rainfall durations between 1-60 min were analyzed in terms of number of events, depth, average intensity and maximum intensity. Results show that the 15-min duration maximum intensity can be used to evaluate erosion risk based on soil erosion type. The developed methodology can be used to evaluate erosion risk in semiarid regions based on exceptional rainfall characteristics. In practical terms the results can be used to better manage catchments that are vulnerable to soil erosion.
\end{abstract}

\section{INTRODUCTION}

High-intensive rainfall contributes to water erosion and sediment transport (e.g., [1-5]). Consequently, strong links exist between storm rainfall characteristics on the one hand and eroded soil amount on the other hand (e.g., [6-10]). During the last decades much experimental and laboratory research work dealing with the relationship between rainfall characteristics and sediment concentration has been performed (e.g., [11-15]). Non-availability of recorded shortterm rainfall data appears to be a major limitation for statistical modeling of soil erosion risk [16]. Observation of hydrological variables in small watersheds at sufficient detail is often lacking [17-19]. This is especially a drawback for areas in the semiarid Mediterranean and the Middle East, since the soil erosion is severe there [20]. These areas often display hydrological changes. The latter, are a combination of climate-induced and anthropogenic effects related to land and water management [21].

Exceptional rainfall events are responsible for most soil erosion occurring under semiarid Mediterranean conditions [5]. According to the above, the objective of this paper is to determine the erosion risk by analyzing intensive rainstorms in semiarid Tunisia. And this, considering the maximum intensity characteristics and the links to soil erosion type. The utilized data are part of a unique high-resolution rainfall data base from 28 catchments collected during an EU-funded project [22]. The paper firstly describes the data base and collection methods. After this, maximum intensities for 1-60

\footnotetext{
*Address correspondence to this author at the National Research Institute for Rural Engineering, Waters, and Forestry, Box 10, Ariana 2080, Tunis, Tunisia; Tel: + 21671230 039; Fax: + 21671717951 ;

E-mail: sihem.jebari@iresa.agrinet.tn
}

min durations within rainfall events are analyzed. Selected durations of these exceptional intensities are related to the risk for different soil erosion types. Finally, practical applications of the results are discussed.

\section{MATERIAL AND METHODS}

\subsection{Study Area and Observed Network}

The Dorsal Mountains represent the last part of the Atlasic Mountain range toward the east (Fig. 1). The major peaks correspond roughly to $1000 \mathrm{~m}$ a.m.s.l. The mountains are often described as the southern boundary of northern Tunisia. The Dorsal corresponds approximately to the 400 $\mathrm{mm} /$ year rainfall isohyet (Fig. 1). Although the annual amount is small, rainfall is often characterized by intense storms during some periods of the year. Annual variation ranges from 250 to $550 \mathrm{~mm}$. Both annual and monthly rainfalls are characterized by a large irregularity. The spatial characteristics of fine time-scale rainfall through the Dorsal were analyzed in a previous study [23]. This paper deals with the statistical time patterns of rainfall and links to soil erosion risk.

Due to specific bioclimatic conditions of the Mediterranean climate, the soils are better characterized by the degradation of rock material rather than their organic matter content. Consequently, they are not well developed and often quite shallow. Moreover, soil erosion is a serious problem throughout the Dorsal area. The soil degradation that characterizes the Dorsal has led to serious soil erosion causing a thinner and uneven soil cover, that display the underlying bare bedrock. It has been estimated that $7 \%$ of the area are badly damaged by erosion and $70 \%$ are moderately damaged. During the decadal strategies, the Dorsal area man- 

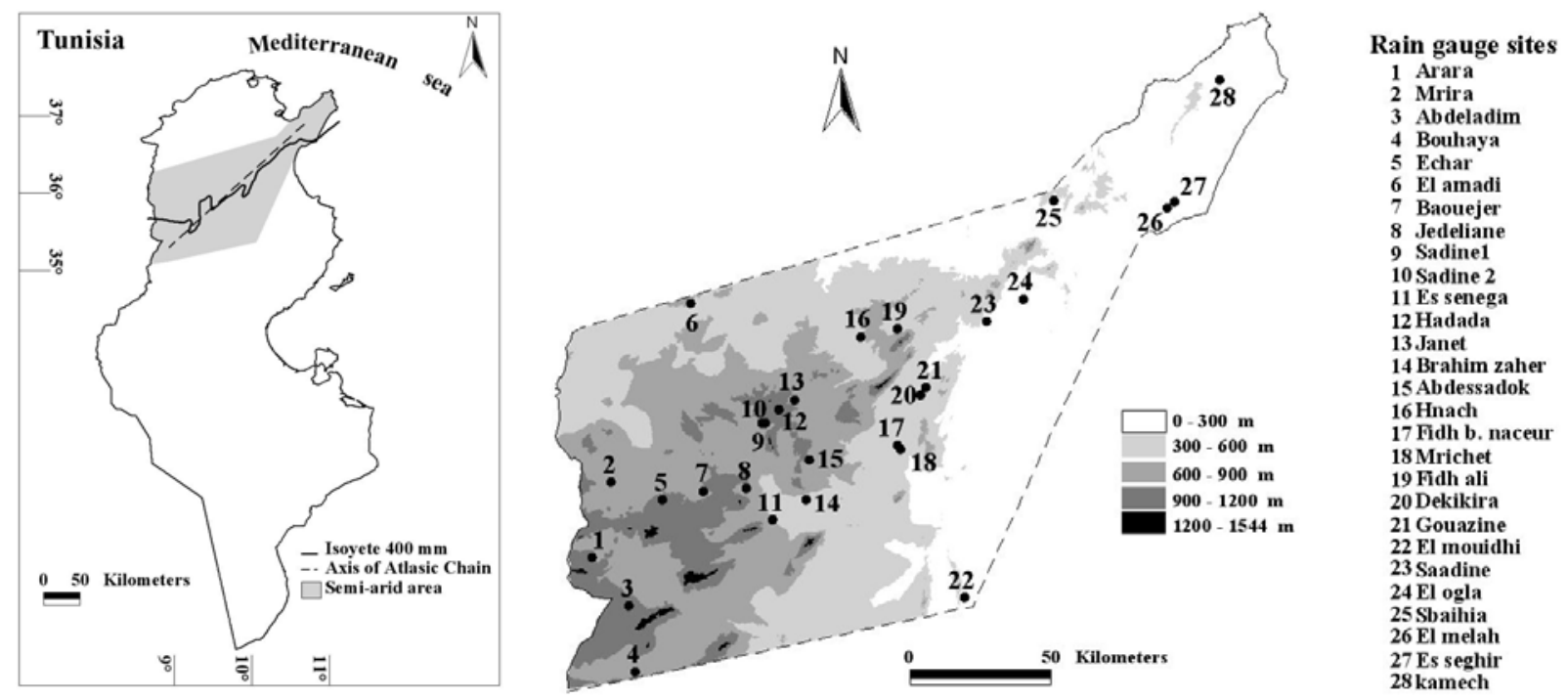

Fig. (1). Study area and observation network.

agement was based on water and soil conservation practices that covered about $20 \%$ of the total area.

In general, the mean annual soil loss in semiarid Tunisia is about 11.5 metric tons/ha/year. This figure was determined according to the deposited sediment volume in the bottom of reservoirs. Wischmeier and Smith [24], amounted soil loss tolerance to 12 tons/ha/year. This value is defined as "the maximum level of soil erosion that will permit a level of crop productivity to be sustained economically and indefinitely". Experiments throughout the Tunisian semiarid area have determined the average tolerable soil loss [25]. This is estimated to be respectively about $2.5,5$, and 10 tons/ha/year for thin, average and thicker soil. With a very slow rate of soil formation in some parts of the Mediterranean region, any soil loss more than 1 ton/ha/year can be considered as irreversible within a time span of 50-100 years [26].

The rainfall gauge monitoring network covers 28 experimental catchments (Table 1). The observation network was set up through the EU-funded Programme HYDROMED (Research program on hill reservoirs in the semiarid Mediterranean periphery, 1992-2002; [22, 27]. At present it is managed by the Tunisian Farmland Conservation and Management Department (DG/ACTA). Each catchment discharges into a small reservoir. An automatic rain gauge is located at each site on the dike itself, as well as an automatic water level recording.

\subsection{Rainfall Characteristics and Soil Erosion Processes}

Raindrop impact initiates detachment of soil particles (rain splash) and causes crust formation [28-30] which seals the surface and limits the infiltration. Once the rainfall intensity exceeds the infiltration rate of the soil, overland flow of water occurs across the land surface, generating hydraulic forces that erode and transport sediments in a down-slope direction [31]. In the Mediterranean areas, very low values of saturated hydraulic conductivities are often found after 10 min of simulated rain [32]. As a consequence of weak aggregate stability of the soil surface, rainfall is often laterally distributed by Hortonian overland flow even for low intensity rainfall [33]. Runoff is the most important direct driver of severe soil erosion [28]. It often occurs at catchment scale, when rainfall intensities reach a minimum threshold of about $25 \mathrm{~mm} / \mathrm{h}$ in $10 \mathrm{~min}$ [e.g., 34]. For other semiarid areas, observations have shown that about $15 \mathrm{~mm}$ rain may be needed to produce 1 to $2 \mathrm{~mm}$ of runoff [2]. High-intensity rainfall events affect runoff generation and erosion processes which are known to be highly non-linear [35]. This is also considered as the major contributor to long-term soil loss [36-38]. The lowest rainfall intensities leading to runoff on humid soil range from about 2 to $23 \mathrm{~mm} / \mathrm{h}$ in Tunisian semiarid areas [39].

Rainfall characteristics determine the erosive action of raindrops and overland flow. They also define the most common water erosion processes namely, interrill, rill, and gully erosion. Interrill erosion concerns uniform removal of soil and is assumed to be the first phase of the erosion process. It affects the largest areas and is of main importance in the erosion process $[15,28]$. When overland flow is concentrated in well defined incisions in the soil surface, turbulent flow occurs and small rivulets are formed. This is known as rill erosion. The rill erosion amount increases with growing water inflow rate and slope [40]. Under extreme storms, rill erosion progresses to gully erosion. the latter, results in large incisions which cause severe damage to the landscape [31] $[41,42]$. Gullies increase the connectivity of the drainage system, and seem to be a main component in sediment delivery [43].

Return period intervals that characterize the rainfall events are crucial in describing the erosion impacts on the landscape. Bull [44] and Hooke [1], showed that important events transporting sediments have a return period of more than 1 to 7 years. Garcia-Ruiz et al. [45] and Coppus et al. [2] described 1-year return period events as mobilizing bed load and 5-year return period events as mobilizing small rock avalanches and channelizing debris flows. According to [46], events with an occurrence of 5 to 15 years considerably change the valley floor. Harvey [47] showed that 25-year event rainfall can modify the channel morphology. Finally, the 100-year return period rainfall shows reactivation of large, deep mass movements and exceptional events with a return period that exceeds 100 years are considered to be a catastrophic geomorphic process [2, 45]. 
Table 1. Description of Observed Rainfall Events for the Dorsal Experimental Rainfall Network (1993 to 2003 )

\begin{tabular}{|c|c|c|c|c|c|}
\hline Rainfall Gauge & Events/Year & $\begin{array}{l}\text { Mean Event } \\
\text { Depth }(\mathbf{m m})\end{array}$ & $\begin{array}{c}\text { Mean Event } \\
\text { Duration (min) }\end{array}$ & $\begin{array}{l}\text { Mean Event } \\
\text { Int. }(\mathrm{mm} / \mathrm{h})\end{array}$ & $\begin{array}{l}\text { Max. Event } \\
\text { Depth }(\mathbf{m m})\end{array}$ \\
\hline 1. Arara & 100.7 & 2.1 & 77 & 4.0 & 40.0 \\
\hline 2. Mrira & 126.1 & 2.4 & 77 & 7.3 & 84.5 \\
\hline 3. Abdeladim & 116.6 & 2.4 & 74 & 3.8 & 52.0 \\
\hline 5. Echar & 133.8 & 2.4 & 76 & 4.3 & 53.5 \\
\hline 6. El Amadi & 180.7 & 3.6 & 94 & 3.8 & 113.0 \\
\hline 7. Baouejer & 155.2 & 2.1 & 75 & 6.4 & 31.0 \\
\hline 8. Jédéliane & 100.0 & 2.9 & 80 & 4.1 & 79.0 \\
\hline 11. Es Senega & 88.8 & 3.0 & 76 & 4.3 & 58.0 \\
\hline 12. Hadada & 170.5 & 2.2 & 84 & 3.5 & 33.5 \\
\hline 13. Janet & 144.2 & 2.7 & 84 & 3.8 & 65.5 \\
\hline 14. Brahim Zaher & 77.7 & 2.6 & 73 & 4.5 & 36.0 \\
\hline 15. Abdessadok & 106.5 & 3.0 & 82 & 4.2 & 78.0 \\
\hline 16. Hnach & 120.1 & 2.6 & 84 & 3.5 & 59.5 \\
\hline 17. Fidh b. naceur & 83.2 & 2.9 & 78 & 5.9 & 42.0 \\
\hline 18. Mrichet El Anze & 136.3 & 2.9 & 89 & 3.5 & 73.0 \\
\hline 23. Saadine & 103.8 & 3.3 & 81 & 4.6 & 74.5 \\
\hline 24. El Ogla & 107.9 & 3.2 & 84 & 3.5 & 84.5 \\
\hline 25. Sbaihia & 135.6 & 2.9 & 85 & 3.5 & 78.0 \\
\hline 26. El Melah & 132.3 & 3.4 & 88 & 3.7 & 56.0 \\
\hline 27. Es Seghir & 135.3 & 3.1 & 85 & 2.9 & 91.0 \\
\hline 28. Kamech & 174.4 & 3.1 & 78 & 5.2 & 125.5 \\
\hline
\end{tabular}

\subsection{Rainfall Data and Treatment}

Twenty eight rainfall gauges from the hydrological network were used in this study (Fig. 1). Missing data were less than $1 \%$ and the gauging density corresponds to approximately 1 gauge per $24 \mathrm{~km}^{2}$ catchment area. Table $\mathbf{1}$ gives descriptive statistics for recorded rainfall events during the analyzed 10-year period (1993-2003). The rain gauges are fully automatic and provide an accuracy of $\pm 4 \%$ up to 250 $\mathrm{mm} / \mathrm{h}$ intensity for a 5-min time step. However, observed rainfall intensity is available down 1-min values [48]. Rainfall intensities could be computed with great accuracy for the range of durations used in the current study. Rain gauges are of tipping bucket type connected to a logger recording data every minute. A total of about 27000 station rainfall events were included in the present analysis. A rainfall event was defined as separated from another event if a rain gauge showed less than one tip per hour. For each rainfall event, duration, accumulated depth, average, and maximum intensity for $1,2,5,10,15,20,25,30,45$, and 60-min durations were determined. Corresponding maximum intensities are hereafter named $I_{1}-I_{60}$. The events with maximum intensities corresponding to a return period superior to one year were kept for further analyses. These events are called exceptional rainfall events. It should be noted that exceptional events of 


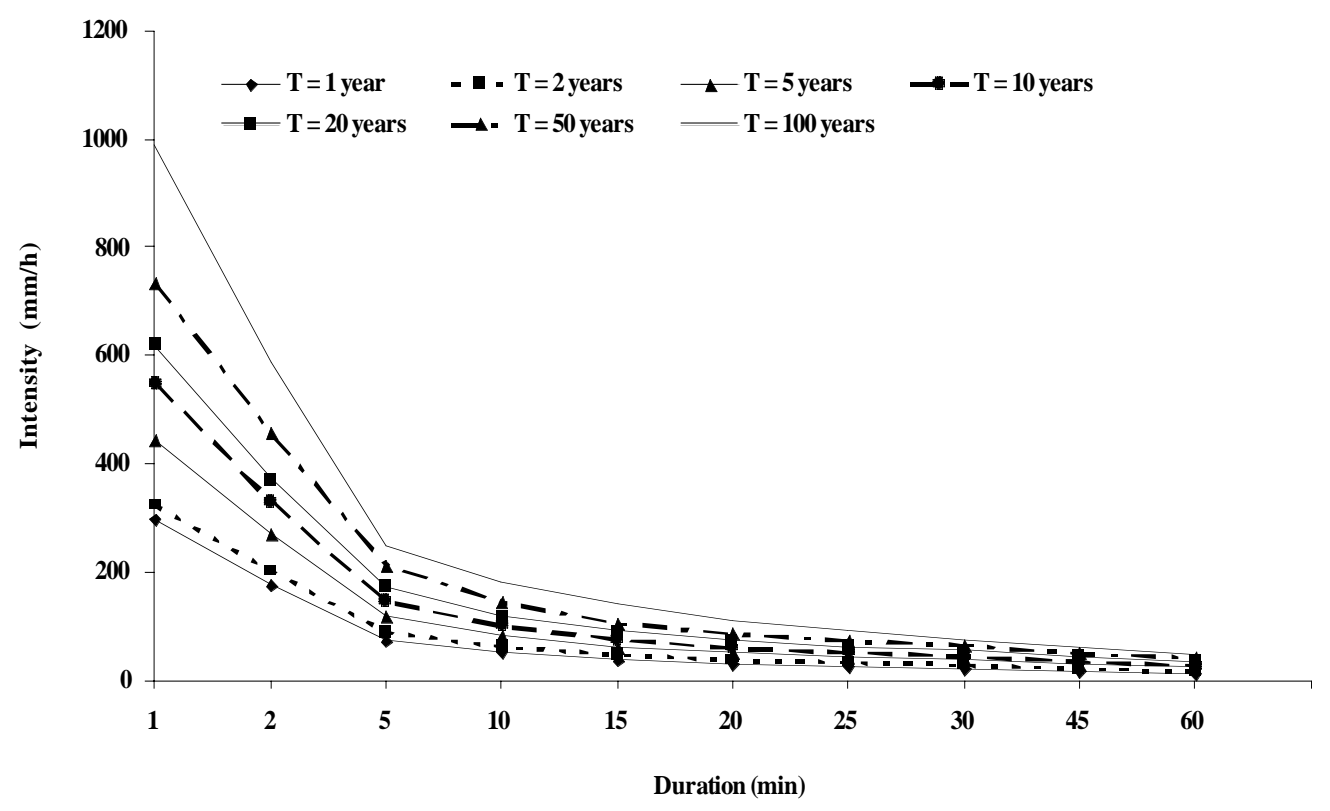

Fig. (2). Intensity-duration-frequency (IDF) curves for short-term rainfall in the Tunisian semiarid region (1964 - 2003).

$$
\square[1-2] \equiv] 2-5] \square] 5-10] \square] 10-20] \quad[20-50] \text { III ]50-100] } \square 100 \text { years }<T
$$

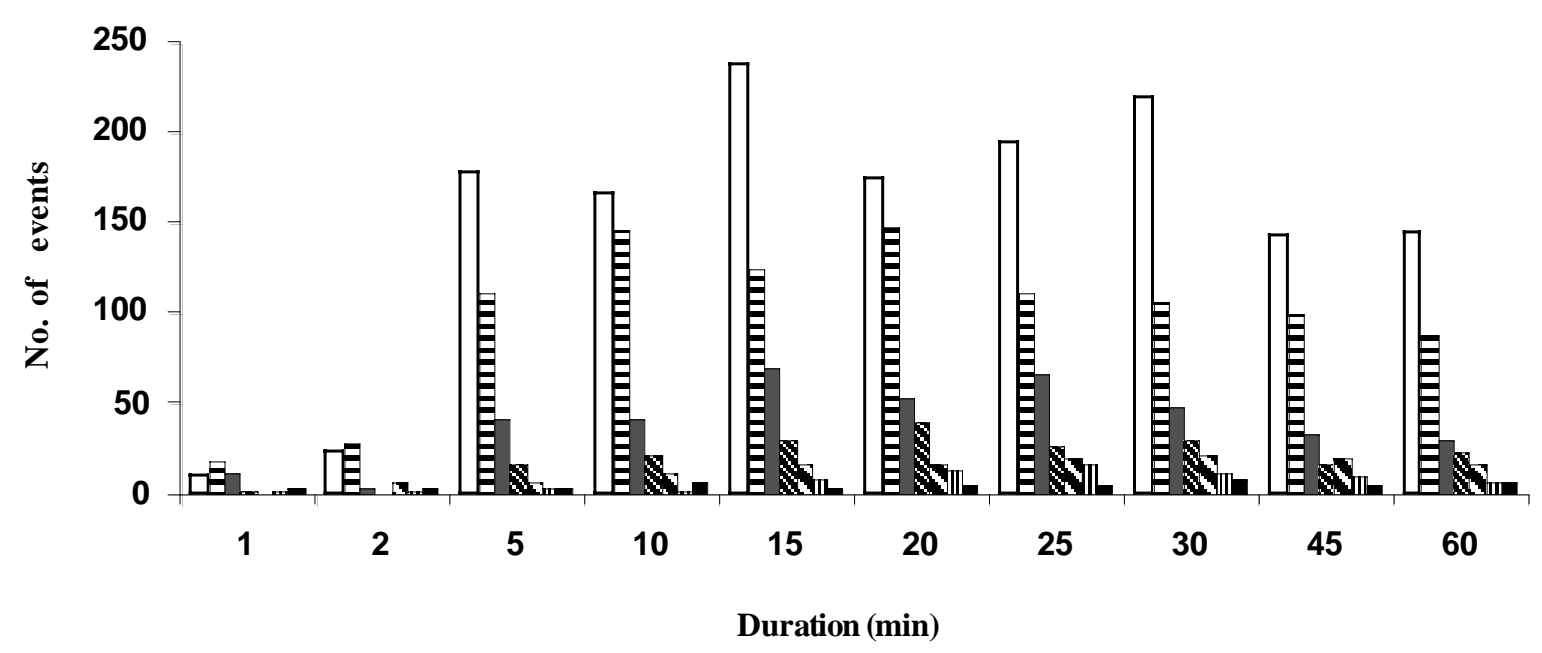

Fig. (3). Identified exceptional rainfall events depending on duration and return period (in total 3350 station events).

certain duration often contain exceptional events with shorter duration.

In order to evaluate the representativity of the observation period as compared to long-term rainfall conditions a number of comparisons were made, particularly in terms of mean rainfall depth and maximum intensities. The longest and most reliable long-term records are from 10 nearby stations in the Dorsal Mountains. The mean annual rainfall for the longer period (1969-2003) was about $406 \mathrm{~mm}$ (standard deviation was $124 \mathrm{~mm}$ ). The same value for the period 19932003 was 365 mm (standard deviation was $102 \mathrm{~mm}$ ). Maximum rainfall intensity for the investigated period was compared to long-term values for different time steps and return periods [49]. Fig. (2) shows intensity-duration-frequency (IDF) curves for the period 1964-2003. As seen in Fig. (3), even if the investigated period was short (1993-2003), it is still representative of longer periods in terms of maximum intensities corresponding sometimes to more than a 100 -year return period.

\subsection{Methods}

The erosive characteristics of rainstorms and the resulting soil erosion process for the Tunisian semiarid area bring up many questions. For example, what is the importance of exceptional rainfall (rainfall intensities corresponding to a return period superior to 1 year) for the erosion risk? What time step is the most important when estimating the erosive potential of rainfall events? Which lower or upper limits of rainfall intensity characteristics could trigger erosion events? What is the most active erosion process in small catchments? Several aspects of the rainfall may be important to define events that lead to soil erosion. Different rainstorm charac- 
teristics, such as return period, duration, maximum shortterm intensity, and rainfall depth may be significant for the soil erosion risk. Many studies during recent years have shown that rainfall return period is one of the most important characteristic indicating soil erosion amount and type. The following relationships are an attempt to summarize important soil erosion research concerning return period and soil erosion type for semiarid areas in general as well as semiarid Mediterranean regions in particular (using the following references in alphabetical order; [50,44,34,2,51,3,45,1,47,52$54,46,37,55-56,38,57-58,7,59,14]$.

1) Interrill erosion: $1 \leq T<5$

2) Rill erosion: $\quad 5 \leq T<10$

3) Gully erosion: $10 \leq T$

where $T$ is rainfall return period in years and the duration of rainfall is 1 to $60 \mathrm{~min}$.

The above relationships can be used in a simplified way, to estimate erosion risk based on short-term rainfall characteristics. It has to be remembered that the relationships are in general only valid for semiarid areas similar to the Atlasic catchments. The return period intervals should also be seen as an approximation for a large number of samples.

\section{RESULTS}

\subsection{General Rainfall Characteristics}

Table 1 shows a summary of nearly 27000 identified station rainfall events during the observation period. The number of more or less independent rainfall events per year corresponds to between 70 and 180. The average number of rainy days is about $22 \%$ ( 80 days/year) for the entire rain gauge network with a maximum of $30 \%$ at Kamech and a minimum of $13 \%$ at Mouidhi. More than $80 \%$ of the events appear as afternoon rains. This is consistent with the convective storm system. The rainfall event duration does not exceed 1 hour in $70 \%$ of the cases. Rainfall events with duration of less than 6 hours represent about $28 \%$ and events superior to 6 hours only $2 \%$. Because of this, the majority of events can be categorized as small meso-scale rainfall ac- cording to House [60]. Only $25 \%$ of the events exceed $3 \mathrm{~mm}$ in depth. This value is the threshold to evaluate the kinetic energy of rainfall [61]. They hold about $70 \%$ of the total rainfall depth and represent $90 \%$ of the rainfall erosivity potential.

\subsection{Exceptional Rainfall Event Characteristics}

The observed rainfall data during the studied period displayed a maximum rainfall event of $125.5 \mathrm{~mm}$ that lasted about 12 hours (Table 1). This corresponds to a daily return period of about 50 years and the highest return period of 20 years for $I_{45}$ and $I_{60}$. Among notable events the maximum values during 10,15 , and 20 min duration were respectively 24, 60, and $74 \mathrm{~mm}$. For 30 and $60 \mathrm{~min}$ duration, 82 and 98 $\mathrm{mm}$, were recorded. These values correspond to about $25 \%$ of the highest recorded rainfall intensity in the world for a duration of $15,20,30$, and $60 \mathrm{~min}$ [62].

The exceptional events represent about $12 \%$ of the annual rainfall station events in semiarid Tunisia (about 10-20 events per year). Exceptional events less than a 10-year return period, represent several hundred station events, while, larger than a 10-year return period corresponds to about 1020 events. According to Fig. (3), the number of exceptional events is unevenly distributed over the 1-60 min durations. One and 2-min duration exceptional events are rare. The 15min duration displays a peak representing about $15 \%$ of all exceptional events. For instance, it displays 130, 45 and 171 more exceptional events than what is noted for the 5, 30 and 60 min durations, respectively. In general, the events occurring throughout the different durations seem to be nearly identical. If we have to choose representative durations for exceptional rainfall events, the 15-min duration, presents some advantages. When using, e.g., the universal soil loss equation (USLE; [24]). The rainfall and runoff erosivity is expressed by the so-called $R$ factor. The $R$ factor is calculated as a product of the total energy of rainfall, $E$ and its maximum 30-min intensity, $I_{30}$. Consequently, the identified $I_{30}$ exceptional intensities could be used to calculate the $R$ factor. However, the $I_{15}$ also displays possibilities to further elaborate on intensity variations within the 30-min duration. Compared to other durations it also displays the lowest stan-

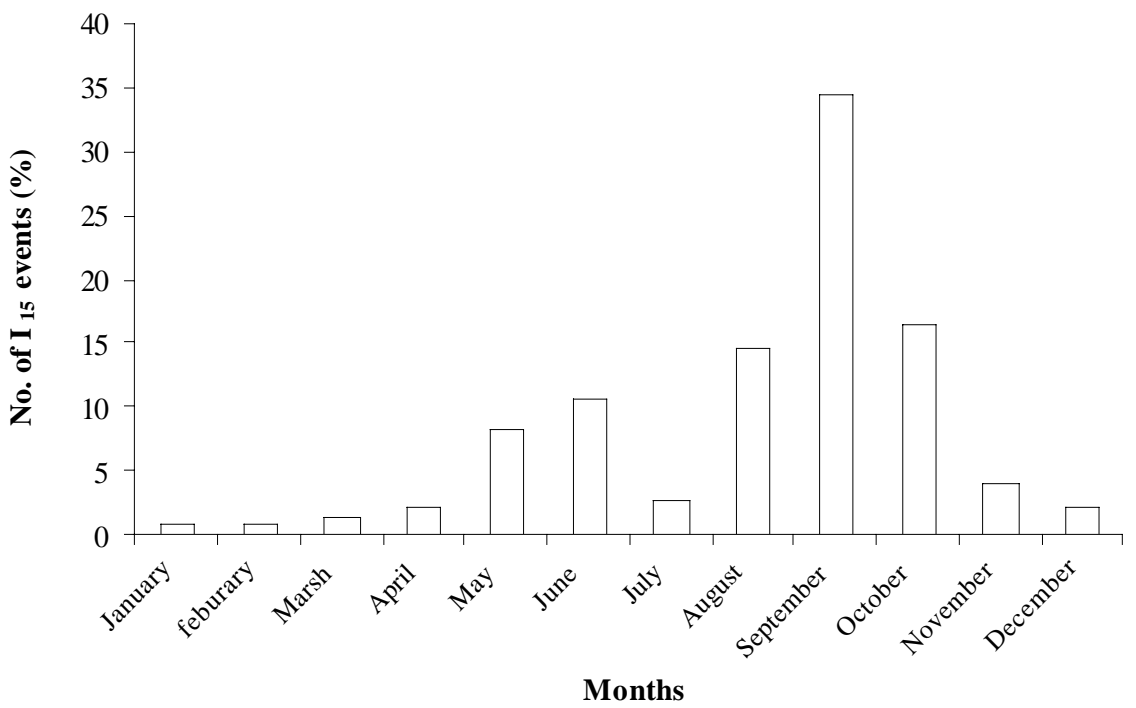

Fig. (4). Seasonality of the identified exceptional rainfall events with 15-min duration (average of about 500 station events). 
Table 2. Description of Identified 15-min Duration Exceptional Rainfall Events. Depth, Intensity, and Return Period Refer to the Maximum Observed Intensity

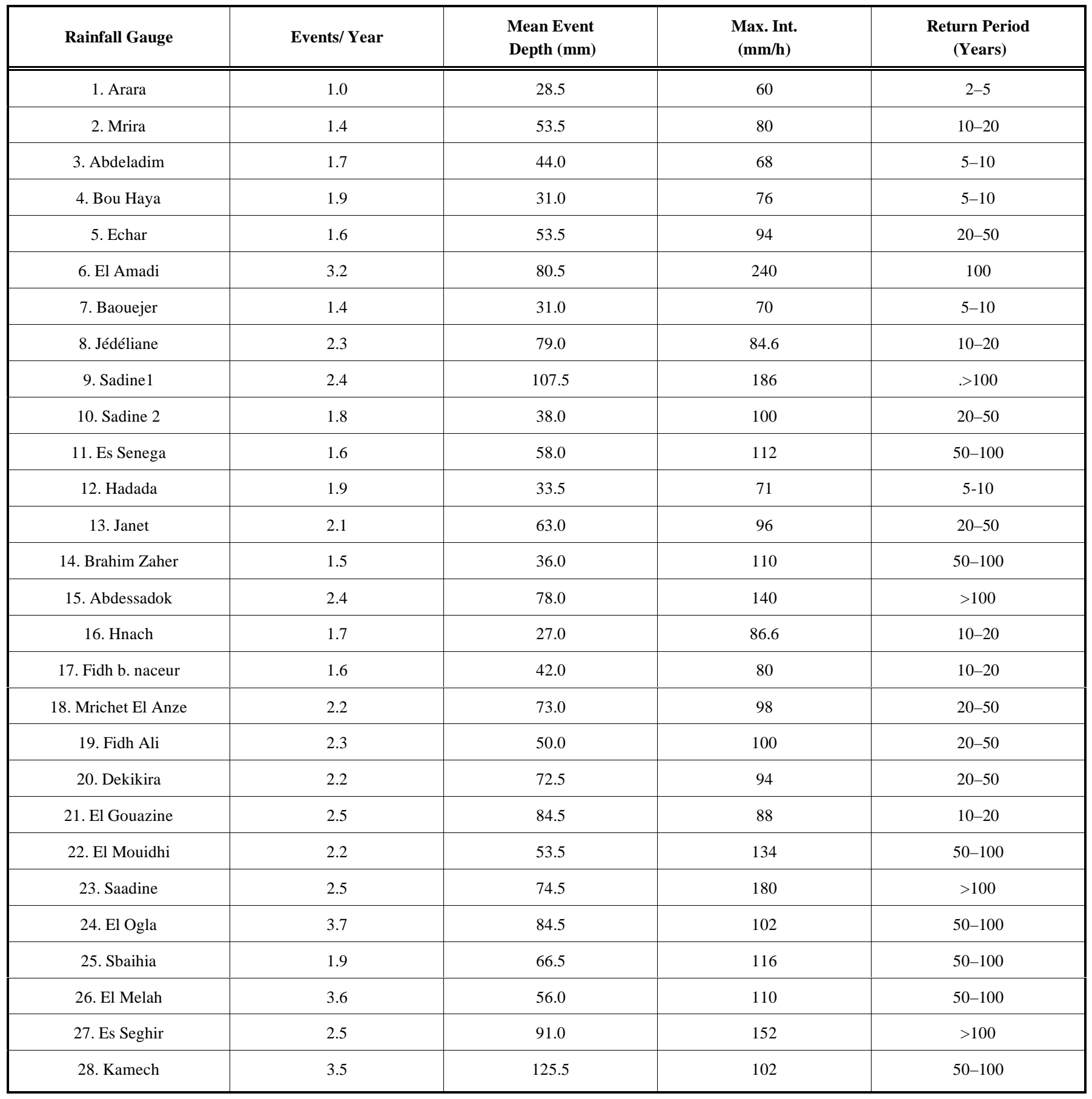

dard deviation $(15.8 \mathrm{~mm})$ for rainfall depth and the smallest coefficient of variation $(37.8 \%)$ linked to the maximum intensity values. In short, the 15-min duration, seems to be the most homogeneous sub-sample of exceptional rainfall intensities and also the most representative duration for erosive rainfall in the Dorsal area.

\section{3. $I_{15}$ Characteristics and Erosion}

Fig. (4) shows inter-annual variation of $I_{15}$ events. As shown in the figure, the majority of exceptional events occur with a major peak during the start of the rainy period in $\mathrm{Tu}-$ nisia between August September and October. During this specific period, the soils are the most vulnerable for rainfall erosion since they usually lie bare after the long dry period.

The average depth and duration for all identified 15-min exceptional events are respectively $25 \mathrm{~mm}$ and $105 \mathrm{~min}$, Corresponding average and maximum intensity are 23 and $56 \mathrm{~mm} / \mathrm{h}$. Table 2 shows a summary of the $I_{15}$ maximum event characteristics depending on station. As seen in the table the return period for these events are often much larger than the 10-year recording period and in several cases larger than 100 years. Consequently, the observation period may well represent a much longer period in statistical terms. The 


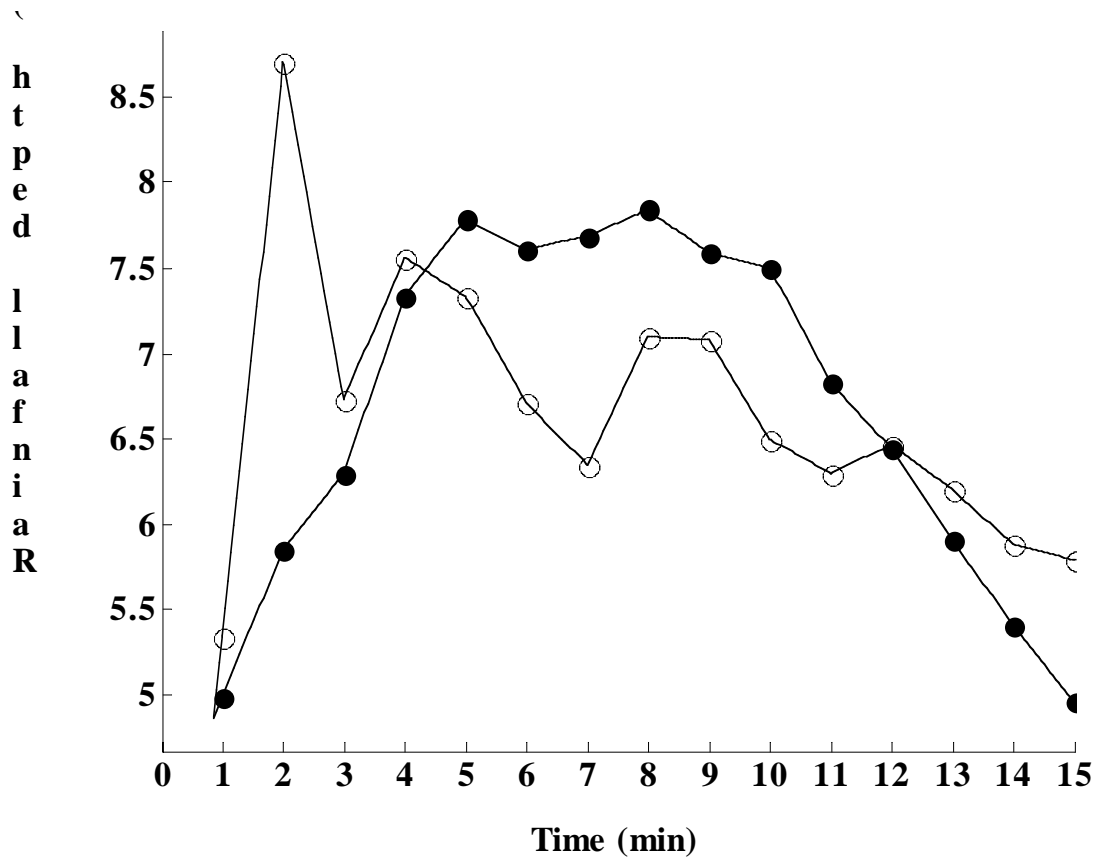

Fig. (5). Temporal distribution of the identified 15-min duration exceptional rainfall events. Line connecting filled circles shows average properties and line connecting empty circles shows standard deviation (about 500 station events).

28 different rainfall stations display varied number of exceptional 15-min duration events. Ogla, Amadi, and Kamech show more than 3 exceptional events per year while Arara only has one single exceptional event per year. The largest observed $I_{15}$ was recorded at Amadi and Sadine 1 with a return period larger than 100 years. The corresponding intensities were 240 and $186 \mathrm{~mm} / \mathrm{h}$ that correspond to respectively 450 and 200 year return period. Largest maximum intensities occur most often east of Mouidhi to Kamech. The western parts usually have the lowest maximum intensities.

Fig. (5) shows the average temporal distribution for the 15-min duration exceptional rainfall events. The distribution appears somewhat skew with a centre of gravity towards the first half of the events. The intensity maximum occurs after about 5-10 min. The standard deviation displays a large variation for the first minutes that then gradually decreases. This indicates that some rainfall events may have large intensities right from the start which can cause great raindrop impact initiating detachment of soil particles.

The erosion types are linked to the different return periods (cf. Methods). Consequently, the risk of erosion appears to be related to specific exceptional 15-min intensities. This yields the following relationships:

1) Interrill erosion: $38 \leq I_{15}<65$

2) Rill erosion: $65 \leq I_{15}<75$

3) Gully erosion: $75 \leq I_{15}$

where $I_{15}$ is the exceptional rainfall intensity in $\mathrm{mm} / \mathrm{h}$.

The above relationships should be regarded as a simplified way to estimate the occurrence of different erosion types depending on the maximum 15-min duration rainfall intensity. As such, the intensity boundaries should not be seen as fixed but rather indicative. Together with additional information on a particular catchment's situation in the soil degrada- tion cycle [63], the relationships can be used to estimate the risk for different types of erosion in the Dorsal region. The results can be used to better manage erosion-prone catchments and also give input to erosion modelling.

\section{CONCLUSION AND DISCUSSION}

Semiarid regions are especially vulnerable to erosion due to a combination of geomorphological conditions, soil management, and the high-intensive character of rainfall. Due to this, there are needs to better develop methods and estimate the erosion risks in a simple way. The most rational means to do this is to start from the rainfall characteristics. About $12 \%$ of all rainfall events in the Tunisian semiarid region are erosive and can be categorized as being exceptional (return period equal and superior than 1 year). A literature survey of pertinent soil erosion research for semiarid regions shows that type of erosion can in a general way be related to rainfall return period. A combination of these results with the conclusions herein show that the 15-min exceptional rainfall intensity can be used to characterize erosive rainfall. And this leads forward to a simplified general relationship for the occurrence of a certain type of erosion. The relationship links erosion type with the 15 -min exceptional rainfall intensity. The results can be used to estimate the risk of certain type of erosion in a simplified way based on short-term rainfall characteristics. Together with information on a certain catchment's location in the soil degradation cycle. Results can be used as input to erosion modeling but also to better manage erosion risks in catchments with water erosion problems.

\section{ACKNOWLEDGEMENTS}

Sihem Jebari and Akissa Bahri thank Mr Habib Farhat, head of the Tunisian Farmland Conservation and Management Department (DG/ACTA) for providing data and all his staff for valuable time and discussions allocated to this work. 
Ronny Berndtsson is supported by the Swedish Research Council.

\section{REFERENCES}

[1] Hooke JM, Mant JM. Geomorphological impacts of a flood event on ephemeral channels in SE Spain. Geomorphology 2000; 34: 163-180.

[2] Coppus R, Imeson AC. Extreme events controlling erosion and sediment transport in a semi-arid sub-andean valley. Earth Surf Process Landforms 2002; 27: 1365-1375.

[3] Dhakal AS, Sidle RC. Distributed simulations of lanslides for different rainfall conditions. Hydrol Process 2004; 18: 757-776.

[4] Jen CH, Lin JC, Hsu ML, Petley DN. Fluvial transportation and sedimentation of the Fu-shan small experimental catchments. Quater Int 2006; 147: 34-53.

[5] Boix-Fayos C, Martinez-Mena M, Calvo-Cases A, Arnau-Rosalén E, Albaladejo J, Castillo V. Causes and underlying processes of measurement variability in field erosion plots in Mediterranean conditions. Earth Surf Process Landforms 2007; 32: 85-101.

[6] Walling DE. Measuring sediment yield from river basin, Soil Erosion Research Methods. Soil and Water Conservation Society. In: Lal, R. Editor 1994.

[7] Uson A, Ramos MC. An improved rainfall erosivity index obtained from experimental interrill soil losses in soils with a Mediterranean climate. Catena 2001; 43: 293-305.

[8] Krishnaswamy J, Richter DD, Halpin PN, Hofmockel MS. Spatial patterns of suspended sediment yields in a humid tropical watershed in Costa Rica. Hydrol Process 2001; 15: 2237-2257.

[9] Romkens MJM, Helming K, Prasad SN. Soil erosion under different rainfall intensities, surface roughness, and soil water regimes. Catena 2002; 46: 103-123.

[10] Vogel RM, Stedinger JR, Hooper RP. Discharge indices for water quality loads. Water Resour Res 2003; 39: 1273-1292.

[11] Walker PH, Kinnel PIA, Green P. Transport of a non cohesive sandy mixture in rainfall and runoff experiments. Soil Sci Soc Am J 1978; 42: 793-801.

[12] Singer MJ, Walker PH, Hutka J, Green P. Soil erosion under simulated rainfall and runoff at varying cover levels. Soils Div Rep CSIRO, Australia 1981.

[13] Kinnel PIA. The effect of flow depth on sediment transport induced by raindrops impacting shallow flows. Am Soc Agr Eng 1991; 34: 161-168.

[14] Zartl AS, Klik A, Huang C. Soil Detachment and Transport Processes from Interrill and Rill Areas. Phys Chem Earth 2001; 26: 2526.

[15] Malam Issa O, Le Bissonnais Y, Planchon O, Favis-Mortlock D, Silvera N, Wainwright J. Soil detachment and transport on fieldand laboratory-scale interrill areas: erosion processes and the sizeselectivity of eroded sediment. Earth Surf Proc Landf 2006; 31: 929-939.

[16] White S, García-Ruiz JM, Martí C, Valero B, Errea MP, GómezVillar A. The 1996 Biescas campsite disaster in the Central Spanish Pyrenees, and its temporal and spatial context. Hydrol Process 1997; 11: 1797-1812.

[17] Berndtsson R. Spatial hydrological processes in a water resources planning perspective. An investigation of rainfall and infiltration in Tunisia. Ph.D. diss., Dept. of Water Resources Engineering, Lund Univ, 1988.

[18] Sur HS, Bhardwaj A, Jindal PK. Some hydrological parameters for the design and operation of small earthen dams in lower Shiwaliks of northern India. Agr Water Manag 1999; 42: 111-121.

[19] Haregeweyn N, Poesen J, Nyssen J, et al. Reservoirs in Tigray (Northern Ethiopia): characteristics and sediment deposition problems. Land Degr Dev 2006; 17: 211-230.

[20] Sivapalan M, Takeuchi K, Franks SW, et al. IAHS Decade on prediction in ungauged basins (PUB), 2003 -2012: Shaping an exciting future for the hydrological sciences. Hydrol Sci J 2003; 48: 857-880.

[21] Cudennec C, Leduc C, Koutsoyiannis D. Dryland hydrology in Mediterranean regions _ a review. Hydrol Sci J 2007; 52: 10771087.
SERST-IRD. Evaluation conjointe du programme de recherché Lacs et barrages collinaires en Tunisie, Technical Report 2000, Tunis 2000 .

[23] Jebari S, Berndtsson R, Uvo C, Bahri A. Regionalizing fine timescale rainfall affected by topography in semi-arid Tunisia. Hydrol Sci J 2007; 52: 1199-1215.

[24] Wischmeier WH, Smith DD. Rainfall energy and its relationship to soil loss. Trans Am Geophys 1958; 39: 285-291.

[25] Masson JM. L'érosion des sols par l'eau en climat méditerranéen. Méthodes expérimentales pour l'étude des quantités érodées à l'échelle du champ. La Houille Blanche 1972; 8 : 673-679.

[26] EEA. Environment in the European Union at the turn of the century, Technical Report 1999, European Environment Agency, Brussels 1999.

[27] Albergel J, Rejeb N. Les lacs collinaires en Tunisie: enjeux, contraintes et perspectives. Comptes rendus à l'Académie d'Agriculture de France 1997; 83: 77-104.

[28] EEA. Assessment and reporting on soil erosion. Background and workshop report, Technical Report 2002, European Environmental Agency, Copenhaguen 2003.

[29] Ellison WD. Soil erosion studies - part I. Agric Eng 1947; 28: 145146.

[30] Greene RSB, Ringrose-Voase AJ. Micromorphological and hydraulic properties of surface crusts formed on a red earth soil in the semi-arid rangelands of eastern Australia, Conference Proceedings, Townsville, Queensland, Elsevier: 1994.

[31] Weggel JR, Rustom R. Soil erosion by rainfall and runoff - State of the art. Geotext Geomembr 1992; 11: 551-572.

[32] Ramos MC, Nacci S. Estabilidad de agregados superficales en suelos del Anoia-penedès (Barcelona) frente al humedecimiento y al impacto de las gotas de lluvia. Edafologia 1997; 3: 3-12.

[33] Cerdan O, Le Bissonnais Y, Govers G, et al. Scale effect on runoff from experimental plots to catchments in agricultural areas in Normandy. J Hydrol 2004; 299: 4-14.

[34] Cammeraat LH. A review of two strongly contrasting geomorphological systems wihin the context of scale. Earth Surf Proc Landf 2002; 27: 1201- 1222.

[35] Kandel DD, Western AW, Grayson RB, Turral HN. Process parameterization and temporal scaling in surface runoff and erosion modelling. Hydrol Process 2004; 18: 1423-1446.

[36] Gilley JE, Eghball B, Kramer LA, Moorman TB. Narrow grass hedge effects on runoff and soil loss. J Soil Water Cons 2000; 55: 190-196.

[37] Martinez-Mena M, Castillo V, Albaladejo J. Relations between interrill erosion processes and sediment particle size distribution in a semiarid Mediterranean area of Spain. Geomorphology 2002; 45: 261-275.

[38] Spaan WP, Sikking AFS, Hoogmoed WB. Vegetation barrier and tillage effects on runoff and sediment in an alley crop system on a Luvisol in Burkina Faso. Soil Till Res 2005; 83: 194-203.

[39] Collinet J, Jebari S. Étude expérimentale du ruissellement et de l'érosion sur les terres agricoles de Siliana, Technical Report 2000, INRGREF and IRD, Tunisia 2000.

[40] Li M, Li Z, Ding W, Liu P, Yao W. Using rare earth element tracers and neutron activation analysis to study rill erosion process. $\mathbf{J}$ Appl Radiol Isot 2006; 64: 402-408.

[41] Bocco G. Gully erosion: processes and models. Progr Phys Geogr 1991; 15: 392-406.

[42] Vrieling A. Satellite remote sensing for water erosion assessment: A review. Catena 2006; 65: 2-18.

[43] Plata Bedmar A, Cobo Rayan R, Sanz Montero E, Gómez Mon$\tan \sim$ JL, Avendan o Salas C. Influence of the Puentes reservoir operation procedure on the sediment accumulation rate between 1954-1994, Conference Proceedings, Florence, Italy 1997.

[44] Bull LJ, Kirkby MJ, Shannon J, Hooke JM. The impact of rainstorms on floods in ephemeral channels in southeast Spain. Catena 1999; 38: 191-209.

[45] Garcia-Ruiz JM, Carlos MB, Adrián L, Santiago B. Geomorphological consequences of frequent and infrequent rainfall and hydrological events in Pyrenees Mountains of Spain. Mitig Adapt Strat Glob Change 2003; 7 : 303-320.

[46] Maas GS, Macklin GE, Warburton J, Woodward JC, Meldrum E. A 300-year history of flooding in an Andean mountain river system: the Rio Alizos, southern Bolivia, Technical Report, Balkema, Rotterdam 2000. 
[47] Harvey AM. Geomorphological response to an extreme flood: a case from southeast Spain. Earth Surf Process Landf 1984; 9: 267279.

[48] Colombani J. Autopsie d'un hyétogramme, Troisièmes journées hydrologiques de l'ORSTOM, Conference Proceedings, Montpellier, France 1988.

[49] DGRE. Optimisation des réseaux de suivi des ressources en eau, étude de la pluviographie, Technical Report, Water Resources Department, Tunisia 2006.

[50] Berguaoui M, Camus H. Etude statistique des averses sur le basin versant de l'oued Ez-zioud: Djebel Semmama, Tunisie Centrale. Les Ann Maghrébines l'Ingénieur 1994; 8: 2-27.

[51] CGR. Les pluies en Tunisie, Technical Report, Centre de Recherches et d'Expérimentation de Génie Rural, Tunisie 1964.

[52] Hollinger E, Cornish PS, Baginska B, Mann R, Kuczera G. Farm scale storm water losses of sediment and nutrients from a market garden near Sydney, Australia. Agr Water Manag 2001; 47: 227241.

[53] Hudson NW. The Influence of Rainfall on the Mechanics of Soil Erosion with particular reference to Northern Rhodesia. MSc. Thesis, Univ. of Cape Town 1965.

[54] Li Y, Poesen J, Yang JC, Fud B, Zhang JH. Evaluating gully erosion using ${ }^{137} \mathrm{Cs}$ and ${ }^{210} \mathrm{~Pb} /{ }^{137} \mathrm{Cs}$ ratio in a reservoir catchment. Soil Till Res 2003; 69: 107-115.

[55] Sempere TD, Creutin D, Salles JD, Delrieu G. Quantification of soil detachment by raindrop impact: performances of classical for- mulae of kinetic energy in Mediterranean storms. Wallingford: IAHS Press 1992.

[56] Sinniger R, Martini O, De Cesare G. Apports de sédiments dans une retenue par courant de densité, Conference Proceedings, Durban 1994.

[57] Steegen A, Govers G, Nachtergaele J, Takken I, Beuselinck L, Poesen J. Sediment export by water from an agricultural catchment in the Loam Belt of Central Belgium. Geomorphology 2000; 33: 25-36.

[58] Thévenin MJ. La sédimentation des barrages-réservoirs en Algérie et les moyens mis en œuvre pour préserver les capacités. Annales de l'Institut Technique du Bâtiment et des Travaux Publiques : Algérie 1960.

[59] Xie Y, Liu B, Nearing MA. Practical thresholds for separating erosive and non-erosive storms. Trans ASAE 2002; 45: 1843-1847.

[60] House RA. The mesoscale and microscale structure and organization of clouds and precipitation in midlatitude cyclones, 1: A case study of a cold front. J Atmos Sci 1980; 37: 568-596.

[61] Kowal JM, Kassam AH. Energy load and instantaneous intensity of rainstorms at Samaru, Northern Nigeria. Trop Agric 1976; 53: 185197.

[62] Shaw EM. Hydrology in practice. London: Chapman and Hall 1994.

[63] Jebari S, Berndtsson R, Bahri A, Boufaroua M. Delineation of spatial soil loss and reservoir siltation rates in semiarid Tunisia. Forthcoming.

This is an open access article distributed under the terms of the Creative Commons Attribution License (http://creativecommons.org/licenses/by/2.5/), which permits unrestrictive use, distribution, and reproduction in any medium, provided the original work is properly cited. 